Beata Bielska, Katarzyna Tamborska

Nicolaus Copernicus University in Toruń

Faculty of Humanities

Institute of Sociology

e-mail: bielska.beata@umk.pl,katarzyna.tamborska@doktorant.umk.pl

\title{
Transnational corporations as entities of informal influence. Some reflections based on the example of their engagement in activities directed at LGBT groups in Poland*
}

\begin{abstract}
The paper explores the assertion about multi-faceted tools of impact used by large corporations that aim to limit the subjectivity of consumers. It is based on the concept of "deep capture" (Hanson \& Yosifon, 2003). Deep capture suggests that the consumers have only the idea of their own subjectivity, and that human behaviour is largely dependent on external situational factors rather than the individuals' dispositions. In this context, the present authors analyse the role of large corporations in shaping the image of LGBT people in Poland. Noteworthy is the consideration to build and strengthen the belief that LGBT people are a group which suffers discrimination, to which anyone should make gestures of support throughout consumer decisions. An overview of the actions of business entities for LGBT groups in Poland allows us state that these actions cannot be called large-scale. The actions of Polish companies can be recognised as not very intense or committed. Western transnational corporations have vast experience in actions for LGBT people, but this is not necessarily the case in Poland.
\end{abstract}

\footnotetext{
* The article is an updated version of the paper published in Polish in the Annales. Ethics in Economic Life, 18(1), 21-31. The article is an element of the projects which were financed by the Nicolaus Copernicus University in Toruń within faculty research grants: No. 2035-H (A potential for change. An analysis of the sexual minority movement in Poland through a social movement theory perspective) and 2038-H (Capture category as an interpretative tool for the actions of large economic entities in conditions of globalization). We would like to sincerely thank Dr. Maciej Gurtowski for his comments on the article.
} 
Keywords: deep capture (deep interception), regulatory capture, LGBT, pink money (pink dollar), corporation

JEL Classification: M14

\section{Introduction}

Transnational corporations are important economic, political and cultural actors on global and local levels. Their role is also analysed in the context of the strength and sovereignty of the modern national state (Baszkiewicz, 2008, p. 15; Sala, 2005 , p. 39), in the context of the effectiveness of various institutions that regulate various aspects of the citizens' lives, such as food, access to medication, or the reception of media content. Researchers working on global processes point to a probable scenario, according to which transnational corporations will take over political and economic initiative from the governments of certain countries (Szalacha-Jarmużek, 2013). As Katarzyna Marzęda (2006, p. 302) concludes, national politics are increasingly influenced by the corporate vision of socio-economic development. In a Polish context, the influence of corporations is analysed, among others, through post-colonial studies (Zarycki, 2009, p. 19).

Although transnational corporations are mostly associated with political and economic influence, their cultural influence is strongly tied to the previous aspects and therefore worth analysing. The word "influence" alone is understood as the actions of entities, which can be intentional or unintentional, and are based in the change of actions or the conditions of the actions of other entities, in a way which is congruent with the interest of the influencing entities.

When referencing the actions of large economic entities, we will use the terms "transnational," "multinational" and "global" synonymously, although these terms can be differentiated (Gierańczyk \& Stańczyk, 2003, pp. 73-83). According to the United Nations, transnational corporations are defined as "mostly incorporated enterprises comprising parent enterprise with a minimum of a 10 percent stake in shares or stocks in foreign companies or foreign affiliated companies" (Sala, 2005, p. 33). Therefore, the focus of our interest is the large social organisations being analysed for their influence on a macro-social level (corporationstate, corporation-public opinion), and impacting on an individual level (consumer). We are also interested in units that are situated outside of the corporation, and not, as in the examples in Maja Biernacka's analysis (2009), functioning within its structure (workers). Corporations are a subject of interest for several disciplines such as economics (cf., for instance, Rosińska-Bukowska, 2009), political science (Tausch, 2012, pp. 79-92), and sociology (Tittenbrun, 1991). This paper focuses on the phenomena associated with the interventions by transnational corporations trying to create a friendly image of a particular actor in globalisation within the environment that surrounds it (clients, lawmakers). The goal of these 
actions is, among others, (1) gaining a favourable attitude from state authorities and working out legislative action that will be beneficial to the company (Miller, 2007) (in later parts of the article we will discuss regulatory capture), as well as (2) creating positive associations in the environment of current and potential clients, through forming a discourse that is beneficial to conducting a particular type of activity, creating trends aimed at particular products and services.

Actions that serve the interests of large corporations are disseminated, conducted in an unclear fashion, and are difficult for the average consumer to identify (Miller, 2007). The consumer knows about the existence of advertising, but most often assumes that they do not influence his/her choices (Hanson \& Yosifon, 2003 , p. 264). Among propaganda strategies that we can identify, for example, financing the activity of non-government organisations with a specific profile, sponsored journalist and expert activity, and specially profiled social campaigns (Burton, 2007, pp. 249-255).

A baseline theory that will undergo verification in this article is the assumption that there exist multi-faceted tools of influence that are used by big corporations that aim at the limitation of the subjectivity of consumers. This is the deep capture concept, developed by Jon Hanson and David Yosifon (2003, pp. 129-346), which underlines the fact that large corporations not only influence government organisations but also the ideas of individuals. In light of this concept, consumers are only under the impression of their own subjectivity while they are actually acting under the conditions created by big actors that reach the entire globe.

It is hard to avoid a reference to the macro changes in Western societiesindividualisation or consumerism analysed as a lifestyle aspect, as well as the reformation of economic life (consumerism as a driving force of the capitalist economy). We can assume that the actions of international corporations are aimed at gaining more profit by becoming a part of these changes, and, as a consequence, maintaining and intensifying these changes. We are, therefore, making a reference to the subjectivity of consumers and their individual decisions, because in current Western culture the individual approach, which refers to the individual's power over their own life and the possibility to make independent decisions, is assumed to be obvious and natural. In his article describing "the discourse of innovation," Tomasz Zarycki points to the way that individualism and self-reliance in the shaping of, for example, a professional career, is developed in corporations (2014, pp. 20-34). Being aware of the differences between the United States (where the concept originated) and Poland, it makes sense to note that the conditions which accommodate the aforementioned actions of corporations are alike. In this aspect, Poland adopts the American neo-liberal model-process that initiated during the time of political transition from the 1980s to the 1990s (Kowalik, 2007, pp. 781-797). One of the typical elements of such a model is the focus on the individual, and not the society (Zawojska, 2006). The conviction of having influence over one's own life can be seen in the most recent Social diagnosis 2015. From $69.2 \%$ in the year 2000 to $84 \%$ in 2015 considered the most recent year of their life to be a successful one. Starting with the 
year 2000, on average $80 \%$ of those surveyed claimed that this fact depended on them (Czapiński \& Panek, 2015, pp. 280-281). In this article, we are going to analyse the potential of using the concept of deep capture in a Polish setting.

\section{Interpretation model}

The deep capture concept describes a vision of consumer action as a response to the conditions created by large economic subjects (Hanson \& Yosifon, 2003, pp. 129-346). For the authors, one assumption is key-that human behaviour largely (although not all of it), depends on external situational factors, and not on the individual dispositions of individuals. An approach which concentrates on an individual's internal characteristics is termed "dispositionism," while an approach which places the characteristics of the situation in the first place is called "situationism." Authors, therefore, propose a new way of looking at the vision of human activity, or a new application of that which social psychology has already established, for research in the field of law, economy, and for the analysis of large corporations' modes of action.

This basic assumption about a seeming subjectivity of the consumer was largely based on the results of a well-known experiment conducted in the 1960s at Yale University (Milgram, 1960/2008). The studies on the influence of authority showed that people predict a much lower level of obedience in a survey which describes such a situation, than when they take part in the experiment themselves. What is more important, the subjects presented a varying level of obedience depending on the changes taking place in particular circumstances in the experiment. According to Hanson and Yosifon, the experiment showed that the decisions of an individual are largely decided by the varying circumstances in which they will find themselves.

An opposite stance is assumed by the social psychologists claiming that finding the causes for behaviour within the internal characteristics of an individual instead of situational circumstances the fundamental attribution error. This error occurs, in part, because one is never able to know the full situational context, and doing so would require a much greater cognitive exertion and engagement (Aronson, 2004, pp. 156-159).

According to Hanson and Yosifon, corporations spread the "dispositionist" vision of a person (the one which considers a person's internal dispositions) and at the same time undertake marketing activity which is based on the assumptions of the "situationist" concept. They attempt to regulate consumer behaviour by changing situational factors, while at the same time allowing the individual to maintain an illusion of subjectivity.

According to Hanson and Yosifon, this is an extension of the tools of influence possessed by economic actors that were described by Stigler (1971) as regulatory capture. Simply put, regulatory capture is based on influencing subjects who carry the responsibility of regulating the activity of large corporations, which 
would show in such a way, that the controllers would be realising the interest of the subjects to the control of which they were assigned. According to Hanson and Yosifon, corporations use tools of influence when dealing with institutions as well as consumers; they "capture" the ideas of the consumer which he has regarding his own subjectivity. In this case, the "capture" has a much deeper meaning, because it reaches the space of general ideas, and it is difficult to perceive them on an individual level because it surrounds various areas of social life with its influence. ${ }^{1}$ According to Hanson and Yosifon, the consumer not only does not notice the dictate of varying circumstances, but he does not even think about their existence. Such a state of things is illustrated by the authors with the example of a runner, who assumes that he and his competitors find themselves in a place of equal chances, and the result of the race depends only on the personal abilities of those running in it (2003, p. 228).

Corporate actors orchestrate the factors that influence how the individuals behave without realizing that their actions are manipulated by external circumstances.

According to the authors, it is not only the representatives of authority or politicians that are a party to the process of capture, but also the scientists, the media, and the widely understood intellectual elite. It sometimes happens that the third "independent" side is intentionally formed and actually financed by corporations, e.g., an internet service that supports the protection of the right to free consumer choices that are limited only by their own sense of responsibility (Hanson \& Yosifon, 2003, p. 249). A more widely discussed situation is the one in which research grants for scientists make it impossible to conduct independent research (pp. 272-274).

\section{Arguments for the deep capture hypothesis}

Hanson and Yosifon's approach seems to be justified and probable because we can identify the benefits received by economic subjects, which become possible to be observed after applying this perspective:

(1) maintaining a "dispositionist" (subjective) vision of a consumer as a sovereign subject, which causes one's vision of themselves to be more positive (2003, p. 228);

(2) it allows for the creation of a conviction that those corporations which maximise profit also maximise common wellbeing, through a supply of the products for which a need is expressed by individuals (pp. 226-227);

(3) the assumption made by the dispositionists translates into a general approach which defies federal regulations because a market of free consumer choices becomes the only regulator (p. 227);

\footnotetext{
${ }^{1}$ For more details on the concept of "capture", which could be found also in the works of K. Marx, cf. Byrne (2018).
} 
(4) the consumer is responsible for all decisions which are made, not the corporation, therefore the consumer himself is responsible for her choices, including - among others-cigarette smoking or eating high-calorie foods (pp. 247-248);

(5) if a consumer is not happy with the result of such competition, she cannot blame anyone but herself-market processes are fair, all she can do is change her choices (p. 228).

\section{The deep capture concept versus LGBT-friendly activity}

The concept of deep capture is a tool which allows for the analysis of so-called behind-the-scenes phenomena, "social actions, which are hidden by the subjects performing them due to fear of sanction" because they usually break social norms (Gurtowski \& Waszewski, 2009, pp. 199-201). However, here we would like to discuss not so much the activities which are purposefully hidden, but those which are not very visible, or purposefully not exposed. This article constitutes an example of the attempt to use the concept described above for the analysis of the corporate activities aimed at sexual minorities (LGBTQ-lesbian, gay, bisexual, transgender, and queer persons) in Poland. The term "sexual minorities" may be problematic in this context, but it is used not as an indicator of a definite sexual or gender identity, but as a determinant of the common history of a movement, its experiences, and postulates. The term LGBTQ also functions in various ways, sometimes as an abbreviation, sometimes with additional categories (I-intersex persons, A-asexual persons, A-allies, heterosexual allied people). In this text, we purposefully do not use the term "gay men and lesbians" or "gay-lesbian" movements, because such descriptions in literature are considered inadequate, and to have an application at most in a historical frame of the movement's development. In the context of the purchasing power of the LGBT community, the term "pink money" (Sielicki, 2014, p. 8) is used; companies which are friendly with the LGBT community are deemed LGBT-friendly and any simulated activity of these companies as pink washing and in a wider setting of international relations, simulated activity by nations as homonationalism (Puar, 2013).

One of the factors which can motivate companies to invest in LGBT-friendly activity is rankings, such as the Corporate Equality Index which has been made since the year 2002 by the Human Rights Campaign Foundation in the USA. This index pertains to the USA companies that are active in Poland, e.g., Coca-Cola, Apple. Medium-sized and large enterprises are analysed, ones which offer fulltime employment to at least 500 people, but basing on the list by the biggest law firms in the USA and on a list compiled by Fortune magazine. A company may also volunteer itself for the ranking. In the most recent report, 947 organisations were graded. The grading was based on surveys filled out by company representatives, which were verified by researchers (an analysis of media reports, law acts, financial documents as well as statements made by individual informers referring 
to possible support of anti-LGBT activity). The ranking's purpose is to grade equal employment opportunities for LGBT persons (including cooperation with suppliers and sellers), worker's benefits (supplying equal benefits to people who are in same-sex relationships as well as their families, and removing unfair differentiation of benefits in the case of transgender persons and their dependents), competence in the organisation of infrastructure pertaining LGBT (implementing anti-discriminatory policies, education, considering the variables of sexual orientation and gender identity in internal research) and the level of its engagement in this area (public support for the LGBT community, a lack of anti-LGBT activity). The ranking pertains the companies' global activity (not only within the USA), and that of its subcontractors and suppliers. The ranking's results are used to put together guides for potential workers and clients of the companies which are being evaluated (Human Rights Campaign Foundation, 2018).

The Foundation for Thought-LGBT Business Forum in Poland is yet another example of the involvement of enterprises in social activity (Drozdowski, n.d.). This organisation functioned from 2012 to 2016. Its goal was favourable actions for the LGBT community - the promotion of the equal treatment of LGBT persons in employment through the creation of a working environment free of discrimination, and through the encouragement of companies to consciously create an image which is LGBT-friendly (Szypuła, 2012). The proposed means of achieving this goal (Fundacja LGBT Business Forum, 2012):

Granting the LGBT Diversity Index award to business and social organisations functioning in Poland or other awards connected to the promotions of equalrights attitudes,

The encouragement and initiation of an exchange of the experiences of workers and managers from the LGBT community, through the organisation of meet-ups, debates and training courses,

The organisation of training courses on the topics of labour law and worker talent management,

Organising the Polish edition of the LGBT Business Forum conference, dedicated to LGBT-related topics in the workplace,

Supplying reliable information through research activity and cooperation with other subjects which deal with marketing research and social opinion research.

In the years 2014-2016, the foundation organised conferences during which businesses received the first awards (Rainbow Bees) and an anti-award (Rainbow Wasp) in Poland, which were supposed to turn attention towards the attitudes which enterprises held towards LGBT matters. In the first edition, awards were received by Google Poland, for the "Most LGBT-friendly company in Poland", British Council in the "Organisation" category (for a full implementing of LGBTfriendly policy), LOT Polish Airlines in the "Surprise" category, (for their action directed at the LGBT community - details follow in a further section of the article), and Barefoot Wine in the category "Initiative and activity" (for openly 
expressing support for LGBT issues, which was shown through the promotion of the brand at LGBT events, including the Equality Parade). The anti-award was received by IBM, for a complete cessation of activity for the LGBT cause after openly supporting EuroPride in 2010. Enterprises were able to take part in the organisation's activity by including themselves in the LGBT Diversity Business Network Platform. State institutions and non-government organisations could also take part in this activity. The platform served as an exchange of good business practice in diversity management. The annual Platform membership of 10,000 PLN was waived. The fee included not only the ability to inform about participate in workshops pertaining to the aforementioned issues, participation in conferences, access to reports, company promotion within forum activity, including the company in the organisation's database, etc.

Platform members included: financial agencies, including mortgage agencies, beauty salons, a travel agency, but not large international corporations. The forum itself informed that

\begin{abstract}
it cooperates with the Polish Private Employer Confederation Lewiatan, through the Forum of Responsible Business within the "Diversity Card" action signed by companies such as Aviva, Orange (TP, Centertel), Orbis, Totalizator Sportowy, or Unilever. [The forum] gained the support of the Embassy of the United States, as well as the Government's head of Equal Treatment Agnieszka Kozłowska-Rajewicz. (retrieved from http://lgbt.biz.pl/partnerzy/2 on May 15, 2014)
\end{abstract}

One of the aspects of this activity was the Market and work environment research of LGBT persons in Poland 2014 study. The goal of this study was a diagnosis of the situation in which LGBT persons find themselves on the employment market, and getting to know their opinions as consumers. Data from an internet survey was collected until the end of March 2014. The report was published in June of the same year, and presented during "Equality Week". This was the first study which was supposed to allow an assessment of the approach presented by LGBT consumers when it came to diversity management. 1,362 respondents took part in the study. The study was not representative - the results cannot be generalized to the entire LGBT community. Nonetheless, it was the first research in Poland addressing these issues, and hence it deserves to be discussed here. When answering these questions, people were allowed to vote for the companies they considered as the most LGBT-friendly. Awards were given by a group of LGBT organisation representatives. The vote was considered, however, it remains unknown as to how it was implemented.

Survey respondents listed the following companies: Google (137 votes), Apple (84), IKEA (83), Coca-Cola (48), Starbucks (43), IBM (35), Microsoft (32), Facebook (28), Nike (18), H\&M (18), Subaru (17), Unilever (15), Oreo (14), Dolce and Gabbana (14), McDonald's (13), Zara (12), HP (11), Absolut Vodka (10), Nivea (10), Disney (10) (Sielicki, 2014, p. 16).

\footnotetext{
${ }^{2}$ The Forum's website was shut down.
} 
LGBT Business Forum stated, that the estimated value of the Polish LGBT market amounts to 2.5 million persons and 140 billion PLN (Szypuła, 2013), however, at times this estimate amounts to 20 billion euro (Sielicki, 2014, p. 9), though no details (base assumptions) of these calculations were given.

During the research on market and work environment, buying decisions depending on how the potential manufacturer treats or refers to LGBT issues were analysed. When answering the following question: "If you found out that the company which manufactures goods or provides services discriminates against LGBT workers, what would be your reaction?" $76 \%$ of people surveyed ${ }^{3}$ stated that they would cease using the services or buying the products of this company.

For $61 \%$ of the persons studied, support for the LGBT community was the basis for choosing one service or product over another, and they would resign from a different company's services or goods ("Does the fact that a company is an LGBT-friendly influence your decision to buy a product or use the services of one company and not its competition, assuming that both products/services are of the same quality and have the same price?") (Sielicki, 2014, p. 35). Nearly every third person declared that at their place of work, anti-LGBT discrimination policies are implemented, and half of them claimed that these procedures are truly in place. Most of the people taking part in the research did not point to any particular solutions of this sort (p. 59). This may point to a certain level of potential when it comes to business activity aimed at the LGBT community. The study was repeated in 2015.

Currently, actions similar to that of LGBT Business Forum, only under a different name, is undertaken by the Pro Diversity foundation (https://prodiversity.pl/). It was established in part by two individuals who were previously active in LGBT Business Forum. However, this foundation has included the LGBT-friendly company index in its activity. It will be announced in the fall of 2018. Declarations made by companies are to be verified with the help of data collected during the general market and LGBT work environment research in Poland. The results achieved by particular companies will be classified, and those which will be in the top five can decide whether or not they want this information revealed (Pro Diversity, 2017). Small spelling errors in two places (pages 7 and 10) and the construction of the ranking point to the fact that the project is based on the model that has been in use since the year 2005 - the Stonewall Workplace Equality Index.

Another strategy for creating change in companies, one less organised but with potential when it comes to mass number, is consumer boycott. The Homopedia-

the free LGBT encyclopedia, [...] functioning next to, and partially as an alternative to Wikipedia, which is suspected of favouring ultra-right communities and nationalistic organisations, as well as introducing biased information pertaining to homosexuality. (Konarski, 2013)

\footnotetext{
${ }^{3}$ From among 1,033 people who answered the question.
} 
promoted a boycott of anti-LGBT companies such as Polski Bus, because its owner financed organisations which opposed same-sex marriage; Ferrero Polska, due to the fact that in the rules of their "Maxi Couple," same-sex couples were excluded from the contest; Zysk i Spółka, because it publishes the writings of Wojciech Cejrowski, who regularly calls homosexuals "fags"; "Rzeczpospolita", because in June of 2009 , when the tolerance march took place, the newspaper published a picture which compared same-sex marriage to zoophilia. (Gąsior, 2013)

Another (unsuccessful) example of an attempt to engage a large Polish company in pro-LGBT business activity is the case of LOT Polish Airlines. On May 8, 2014, the Polish airlines placed a rainbow flag on its website and encouraged travel to places which are LGBT-friendly. After one day, the company neutralised the message somewhat into Friendly-travel (www.lot.com/pl/pl/friendly-travel). The company left the flag and the sentence "Plan your vacation in the hip, LGBTfriendly places in the whole world which are pulsing with life." A picture of a male same-sex couple was removed. The writing now spoke of "places friendly to everyone."

The media, politicians and LGBT organisations quickly reacted to LOT's actions. They were criticised from both sides: for creating an LGBT-friendly message (from what is considered the right wing) and for withdrawing from this message (PR companies, LGBT organisations) (Karpieszuk, 2014).

This example shows the specifics of the reception of LGBT-related content in Poland and how little thought is given to the actions taken by LOT. One can only assume that they could have been a simple copy of the campaigns done by western companies - without considering the context of these actions and image repercussions. Political influence was also suggested as a motivation for LOT's actions.

Another example of an attempt at engaging companies in LGBT activity was the "QueerCard" ("QueerKarta")—an initiative by the Equality Factory in Lodz. ${ }^{4}$ The goal of his project was the creation of a network of various service points which declare themselves as open to all guests, regardless of their ideals, sexual orientation or gender identity. The QueerCard entitled its owner to lower prices in selected spots, and the card itself could be acquired during events organised by the Equality Factory. The project was joined by restaurants, clubs, hostels, beauty salons, sex shops, and a job training company (http://fabrykarownosci.com/tml/). The project is not currently continued, discounts are no longer offered.

The best known and popular enterprises which are engaged in making offers to the LGBT community are so-called "industry clubs" ("kluby branżowe" in Polish) such as HAH in Poznan and Sopot, and Red in Bydgoszcz. A small Polish company, LGBT OUTFILM, provides film distribution services. It is difficult to compare these steps to the initiatives of bigger companies.

\footnotetext{
${ }^{4}$ A similar project was run in Poznan by the Stonewall group - they created a map of LGBT-friendly places.
} 
The QueerCard only pertained to the area of Lodz, and large corporations did not engage in this activity. Hence, an influence of business on creation of LGBTfriendly climate should not be overestimated.

LGBT organisations in Poland are relatively likely to complain about a lack of business support. The Equality Parade did not gain a significant sponsor until the year 2014-Norway Funds ("Fundusze Norweskie sponsorem Parady Równości," 2014). In Poland, there are no examples of large companies which strongly underline a positive attitude towards the LGBT community (Gąsior, 2013).

The above actions pertain only to the element of deep capture, which refers to the support of organisations by creating an environment which is friendly towards business.

One should also notice the role of such an initiative in building a conviction of the fact that LGBT persons constitute a minority which is discriminated against, towards which anybody can make gestures of support through their decisions as consumers. We can assume that such a definition of the situation will influence the consumer's self-esteem positively that, in time, may support a weaker minority in the name of "equal treatment." While the activity of Polish companies remains minimal, Western supranational corporations have significant experience in activity aimed at supporting the LGBT community, but not necessarily in Poland. Among the companies which are recognised as openly supportive of the LGBT community, we have such companies as Nike (http://nikeinc.com/lgbt) which supports LGBT organisations or demonstrating their support through footwear design, Unilever which is judged as the best supporter of its LGBT employees in international rankings (Stein, 2014), or IBM in which the initiator of LGBT Business Forum was employed and where he dealt with LGBT issues. It is worth noting that support for LGBT persons in corporations is usually an element of diversity management, which also encompasses support for women, people of colour, or persons with disabilities. The basis of these policies is the conviction that diversity is not only beneficial for the image of the company, but it also simply pays off - thanks to these policies talented workers are not excluded simply by their belonging to a group which is considered discriminated against, and workers which are treated better are more motivated, more effective and less likely to leave; diverse employees recognise the needs of diverse consumers better, and therefore consumers which are often ignored (untapped market segments (Sears $\&$ Mallory, 2011)) or especially wealthy (presenting a greater purchasing power in comparison with the general population with children (Paul, McElroy \& Leatherberry, 2011, pp. 110-111)). Sometimes, the public institutions are the motivating factor for change when they commission projects that demand the implementation of anti-discriminatory policies; sometimes this is done through civil's unions (Sears \& Mallory, 2011, pp. 6-7). 


\section{Downsides and upsides of the concept}

An important disclaimer when it comes to the concept of deep capture is its reference to the category of value attribution. Despite the fact that the authors of the concept use it mainly to depict actions which are judged as negative, it does not necessarily have to be so.

A good example here may be the actions which aim at supporting the LGBT community. It is worth noting that depending on the viewpoint, these will be proequality actions, democratic ones, actions which are pro-diversity, freedom and social justice, while from a different perspective this will be a promotion of inappropriate, irresponsible, family-toxic sexual practices. In the latter form, it will also be the copying of Western patterns which are destructive to society and its citizens, while in the first it will be an adaptation to better Western examples.

Amongst the possible difficulties in applying the deep capture concept to the analysis of corporate activity, we can list a methodological problem - it is hard to point out cause and effect relationships, direct motivations of corporations related to, for example, a reformation of the public sphere according to their business interest.

This argument can be countered by claiming that enterprises strive towards an avoidance of the actions that may cause financial loss, therefore the actions that are aimed at supporting of the LGBT community through the support of nongovernmental organisations are a rational business calculation (the LOT case does not necessarily confirm this). From a different viewpoint, these are strategies in which it is difficult to pinpoint a direct translation into profit, although an attachment of LGBT persons to gay-friendly brands has been reported (Sears \& Mallor, 2011, p. 116). Considering this, it is worth marking that not all the actions of LGBT-friendly corporations have to, in their entirety and at every level, only be an attempt at gaining profit. They may be a result of the convictions of the owners or employees of companies, and may be made regardless of the financial benefits, and even at a risk for loss. As stated by one of the researchers of globalisation processes, Joanna Szalacha-Jarmużek, the question of whether or not an outsider can establish the intention with which a particular subject that appears in the analysed process made a given action is one of the most difficult questions in social sciences. We can only test the effects of these actions and hypothesise about the motives that caused them (Szalacha-Jarmużek, 2013, p. 17).

However, the moral evaluation of particular marketing campaigns, which create trends for a particular product, or underline particular elements of employment policy, becomes secondary. What seems important is the extent to which the concept of deep capture allows for a presentation of the mechanisms which form the approach to the general rules of the functioning of an economy. This is a perspective which allows us to notice the common interests of big corporationsmaximizing market possibilities, and minimizing limits and government regulations. This is demonstrated by the functioning of supranational trade organisations created from subjects which serve common interests, and sometimes only appear to be competing with each other (price fixing). 
Sometimes, however, as is the case with the LGBT community, while on the surface, the activity of a corporation may seem important; a deeper analysis may reveal that it is overemphasised, and that it is easy to overstate its meaning. We can then speak of a potential area for a corporation's activity, not necessarily a real one. The action ns of a corporation can be clearly visible in other areasthis is why they are worth further analysis. An example of an area for such an analysis can be, for example, the (de)regulations pertaining to the food industry, as well as energy sourcing and environmental protection. We can, therefore, ask how much influence corporations have over what products we consider healthy, and what products we avoid, what energy sources we use and what new energy sources we allow or not, do they form trends for particular behaviours, attitudes, and even social movements in an organised and intentional way. We can only try to analyse such activity in the context of behind-the-scenes phenomena, ones which are more difficult to detect and analyse (Gurtowski \& Waszewski, 2009, p. 167), as well as the context of divisions into a centre, peripheries and semiperipheries.

\section{References}

Aronson, E. (2004). Człowiek istota społeczna. Warsaw: Wydawnictwo Naukowe PWN.

Baszkiewicz, J. (2008). Społeczne zobowiazania nauk politycznych. Warsaw: ELIPSA.

Bielska, B., \& Tamborska, K. (2015). Ponadnarodowe korporacje jako podmioty nieformalnego wpływu na przykładzie zaangażowania w działania skierowane do osób LGBT w Polsce. Annales. Ethics in Economic Life, 18(1), 21-31.

Biernacka, M. (2009). Człowiek korporacji. Od normatywizmu do afirmacji własnego Ja. Warsaw: Scholar.

Burton, B. (2007). Unmasking public relations. In W. Dinan, \& D. Miller (Eds.), Thinker, faker, spinner, spy. Corporate PR and the assault on democracy (pp. 247-260). London: Pluto Press.

Byrne, P. (2018). Capture explained. http://www.deepcapture.com/2008/01/a-general-the ory-of-capture//

Czapiński, J., \& Panek, T. (Eds.). (2015). Diagnoza społeczna 2015. Warunki i jakość życia Polaków. http://www.diagnoza.com/

Drozdowski, M. (n.d.). Likwidacja Fundacji LGBT Business Forum [Warszawa]. http:// warszawa.ngo.pl/wiadomosc/2000056.html

Fundacja LGBT Business Forum. (2012). Statut „Fundacji LGBT Business Forum”. https://archive.is/1ZIK7

Fundusze Norweskie sponsorem Parady Równości. (2014). http://queer.pl/news/194699/ fundusze-norweskie-sponsorem-parady-rownosci

Gąsior, M. (2013). Homoseksualiści nie jedza Nutelli i nie jeżdża Polskim Busem? Czarna lista Homopedii radzi bojkot nietolerancyjnych firm. http://natemat.pl/85175, homo seksualisci-nie-jedza-nutelli-i-nie-jezdza-polskim-busem-czarna-lista-homopedii-radzi-ktore-nietolerancyjne-firmy-bojkotowac 
Gierańczyk, W., \& Stańczyk, A. (2003). Korporacje międzynarodowe w przestrzeni globalnej. In Z. Zioło, \& Z. Makieła (Eds.), Kształtowanie się struktur przemystowych (pp. 73-83). Warszawa-Kraków: Prace Komisji Geografii Przemysłu, No. 5.

Gurtowski, M., \& Waszewski, J. (2009). Redukcja do jawności. O pomijaniu zjawisk zakulisowych w badaniach socjologicznych. In A. Bąk, \& Ł. Kubisz-Muła (Eds.), Metody, techniki i praktyka badań społecznych (pp. 199-217). Bielsko-Biała: Wydawnictwo Naukowe Akademii Techniczno-Humanistycznej.

Hanson, J., \& Yosifon, D. (2003). The situation: An introduction to the situational character, critical realism, power economics, and deep capture. University of Pennsylvania Law Review, 152, 129-346.

Human Rights Campaign Foundation. (2018). Corporate Equality Index 2018. Rating American workplaces on lesbian, gay, bisexual and transgender equality. https://as sets2.hrc.org/files/assets/resources/CEI-2018-FullReport.pdf?ga=2.148892855.12621 04800.1516973879-1619114059.1516973879

Karpieszuk, W. (2014). LOT już nie promuje podróży dla gejów. „Stchórzyli”. http://wybor cza.pl/1,75248,15934778,LOT_juz_nie_promuje_podrozy_dla_gejowStchorzyli.html

Konarski, L. (2013). Cenzorzy z Wikipedii. https://www.tygodnikprzeglad.pl/cenzorzy-wiki pedii/

Kowalik, T. (2007). Polska transformacja a nurty liberalne. Ekonomista, 6, 781-797.

Marzęda, K. (2006). Proces globalizacji korporacyjnej. Bydgoszcz: Oficyna Wydawnicza Branta.

Milgram, S. (2008). Postuszeństwo wobec autorytetu. Kraków: Wydawnictwo WAM.

Miller, L. (2007). Powers behind the throne: Washington's top political strategists. In W. Dinan, \& D. Miller (Eds.), Thinker, faker, spinner, spy. Corporate PR and the assault on democracy (pp. 53-66). London: Pluto Press.

Paul, A. K., McElroy, T., \& Leatherberry, T. (2011). Diversity as engine of innovation. https://www2.deloitte.com/content/dam/insights/us/articles/diver sity-as-an-engine-ofinnovation/US_deloittereview_Diversity_as_an_Engine_of_Innovation_Jan11.pdf

Pro Diversity. (2017). Index of workplace equality in Poland 2017. Guidance for entering. http://prodiversity.pl/wp-content/uploads/2017/04/pro_diversity_iwep2017_guidance.pdf

Puar, J. (2013). Rethinking homonationalism. International Journal of Middle East Studies, 45(2), 336-339. doi: 10.1017/S002074381300007X

Rosińska-Bukowska, M. (2009). Rola korporacji transnarodowych w procesach globalizacji: kreowanie globalnej przestrzeni biznesowej. Toruń: Duet.

Sala, S. (2005). Rozwój korporacji transnarodowych w gospodarce światowej. Przedsiębiorczość - Edukacja, 1, 33-44.

Sears, B., \& Mallory, Ch. (2011). Economic motives for adopting LGBT-related workplace policies. https://williamsinstitute.law.ucla.edu/wp-content/uploads/Mallory-Sears-Cor p-Statements-Oct2011.pdf

Sielicki, J. (2014). Raport badania rynku i środowiska pracy osób LGBT 2014. Replika, 50.

Stein, J. (2014). Unilever named best place to work by human rights campaign for seventh year. https://www.unileverusa.com/news/press-releases/2014/unile ver-named-bestplace-to-work-by-human-rights.html

Stigler, G. (1971). The theory of economic regulation. Bell Journal of Economics and Management Science, 2(1), 3-21. 
Szalacha-Jarmużek, J. (2013). Instrumentarium globalnego panowania. Poznań: Wydawnictwo Zysk i S-ka.

Szypuła, T. (2012). Powstała Fundacja LGBT Business Forum. http://tomekszypula.natemat. $\mathrm{pl} / 23345$,powstala-fundacja-lgbt-business-forum

Szypuła, T. (2013). Czy biznes może mieć wkład w równość? http://docplayer.pl/ 205564Czy-biznes-moze-miec-wklad-w-rownosc-warszawa-25-02-2013-tomasz-szypula-1 gbt-business-forum.html

Tausch, A. (2012). Globalizacja a przyszłość rozwoju i demokracji w Europie. Wnioski z nowej analizy ilościowej. Sprawy Międzynarodowe, 1, 79-92.

Tittenbrun, J. (1991). Instytucje finansowe a własność kapitału akcyjnego. Poznań: Nakom.

Workplace Equality Index. http://www.stonewall.org.uk/workplace-equality-index

Zarycki, T. (2009). Peryferie: nowe ujęcia zależności centro-peryferyjnych. Warsaw: Scholar.

Zarycki, T. (2014). Innowacjonizm jako legitymizacja. Dyskursy innowacji, gospodarki opartej na wiedzy, społeczeństwa informacyjnego i pokrewne w perspektywie krytycznej. Zarządzanie Publiczne, 1(27), 20-34.

Zawojska, A. (2006). Liberalizm, neoliberalizm, wolność ekonomiczna i polityczna a rozwój gospodarczy kraju. Zeszyty Naukowe SGGW, 58, 5-23.

Zybertowicz, A. (2009). Kontrola społeczna trzeciego stopnia. In J. Kwaśniewski, \& J. Winczorek (Eds.), Idee naukowe Adama Podgóreckiego (pp. 152-178), Warsaw: Polskie Towarzystwo Socjologiczne, Instytut Profilaktyki Społecznej i Resocjalizacji Uniwersytetu Warszawskiego.

http://fabrykarownosci.com/tml/

http://lgbt.biz.pl/partnerzy/ 